\title{
10. Financing support schemes for SMEs in China: Benefits, costs and selected policy issues
}

\section{Qin Gou and Yiping Huang}

Until the Global Financial Crisis (GFC) in 2008, China had achieved 9.75 per cent annual GDP growth since its economic reforms began in 1978, making it one of the fastest-growing economies in the world-sometimes described as the 'China miracle' (Lin et al. 1996). Small and medium-sized enterprises (SMEs) played an important role in that economic growth. According to the National Bureau of Statistics of China (NBS), 99.6 per cent of enterprises in China were SMEs at the end of 2005 and they accounted for 59 per cent of GDP, 60 per cent of total sales, 48.2 per cent of taxes paid and about 75 per cent of employment in urban areas (Shen et al. 2009). Since 2008, the Chinese economy has switched to a slower lane of economic growth (Huang et al. 2013; Zhang and Gou 2016). To promote economic growth and create more job opportunities, the sound development of SMEs is vital. But, in contrast to their contribution to economic growth, SMEs' difficulty in obtaining external financing from formal financial institutions is widely recognised (Allen et al. 2005; Chong et al. 2013; Gou et al. 2018).

In fact, the major external source of SMEs' financing is bank loans (Beck et al. 2008), but the problems of information asymmetry, moral hazard and adverse selection that typically plague lending (Stiglitz and Weiss 1981) affect SMEs most severely. And this seems to be even more true in China, where, according to the World Bank's Investment Climate Survey in 2012, 49.1 per cent of surveyed SMEs were credit rationed (Gou et al. 2018). A lack of appropriate financing channels and credit unavailability have become the main hurdles for the development of SMEs (Bai et al. 2006; Shen et al. 2009; Du et al. 2012).

The Chinese Government has long recognised the problem and even raised it to the national development agenda, resulting in the Law of the People's Republic of China on Promotion of Small and Medium-sized Enterprises in 2003 and amendments to this law in 2018. This law was enacted to improve the business environment for SMEs, promoting their sound development, creating more job opportunities and promoting entrepreneurship and innovation. One of the important amendments to this law in 2018 was to place separate emphasis on support from the financial sector-which had been included with fiscal funding supports in the original version of the law— to meet the demands of the SMEs and better match their financial structure. 
A set of specific financing support schemes for the banking sector was authorised. Among them, the China Banking Regulatory Commission (CBRC) implemented a policy in 2008 aimed at increasing credit support to SMEs, which is usually referred to as the 'double no-lower-than' policy. This policy required that the growth rate of SME loans should not be lower than the growth rate of the total loans and the increase of SME loans should not be lower than that in the previous year. This policy was dynamically adjusted by relaxing the requirements in 2011 and tightening them again in 2015.

In light of SMEs' financing problems and the policy implications, this chapter aims to analyse whether the financing support scheme for SMEs in China has effectively promoted banks' credit allocation to SMEs. Specifically, we focus on the impact of the policy that assesses banks' SME loans since 2008, based on bank branch-level survey data from China. Following the CBRC's regulations on SME loans, more banks began to evaluate the loans to SMEs internally, to meet the new regulations. This provides us with the possibility of event studies on how the SME financing support policy affects banks' decisions on loans to SMEs.

In regard to lending to SMEs, small banks have a comparative advantage while large banks tend to favour transaction-based lending to non-SMEs. This is because small banks tend to interact much more personally with their borrowers, are able to utilise more soft information and provide more relationship loans to SMEs (Berger et al. 2002). The 'small bank advantage' hypothesis is supported by many empirical studies (Berger and Udell 1995, 1996; Peek and Rosengren 1998; Cole et al. 1999).

However, China's banking sector is still dominated by large banks-in particular, the four largest state-owned banks, known as the 'big four': Bank of China, China Construction Bank, the Industrial and Commercial Bank of China and the Agricultural Bank of China. With the implementation of China's reform and opening-up policies in 1978, other types of banks were set up, including regional banks (which, in large part, are owned by local governments), rural credit cooperatives and joint-stock banks that have comparatively low levels of government ownership and have progressively increased their market share (Allen et al. 2012). In November 2013, the Third Plenary Session of the eighteenth Central Committee of the Communist Party of China allowed qualified private capital to establish financial institutions, such as small and medium-sized banks; five banks entirely funded by private capital were given the green light by authorities in 2014. However, domination by the large state-owned commercial banks continues and the entry of new players is still extremely limited. According to the CBRC, in 2017, the asset share of the largest commercial banks was still 36.8 per cent, the national equity banks held 17.8 per cent and rural and city commercial banks held 25.6 per cent. 
Therefore, one concern about the above CBRC policy is that it may bring costs to the large banks as they are disadvantaged in lending to SMEs. In this chapter, we investigate the influence of the policy on banks of different size. More importantly, we investigate whether this policy brings costs for banks in terms of credit risk and reduced profits.

The rest of the chapter is organised as follows: section two describes the sources of the data used in our empirical analysis and presents some summary statistics; sections three to five present the results of how financing schemes affect banks' credit allocation to SMEs, banks' credit risk and their profits, respectively. Section six summarises and section seven provides conclusions.

\section{Bank-level statistics of SME financing schemes}

\section{Data source}

The data used in this study are from the Financial Ecological Environment Survey (FEES), conducted by the research group of the National School of Development at Peking University in 2014. The survey is retrospective, with most of the variables covering the period 2005-13. Fourteen provinces were selected from the survey on the basis of their economic development and geographical location: Zhejiang, Jiangsu, Guangdong, Fujian and Shandong to represent provinces in the more developed eastern coastal region; Hubei, Jilin, Hunan and Jiangxi to represent the central provinces; and Shaanxi, Sichuan, Chongqing, Guizhou and Ningxia Autonomous Region for western China.

Our data cover county-level districts (hereafter referred to as counties) in both rural and urban areas, which greatly reduces the possibility of selection bias and justifies the representativeness of the data (Shen et al. 2009). The final survey sample covers 90 counties - 47 rural and 43 urban counties-according to the standard county codes provided by the NBS.

The survey covered 892 financial institutions in the 90 sampled counties, belonging to 185 legal institutions. Among them, there are 315 branch offices of the four big state-owned commercial banks (a share of 38.7 per cent). There are 84 branches of the Postal Savings Bank of China, 160 branches of the national joint-stock commercial banks, 105 city commercial banks, 141 rural financial institutions (including rural commercial banks, rural credit cooperatives and rural banks) and 10 branches of foreign banks. The survey covered all types of banking institutions in China. The sample distribution of the institutions is shown in Table 10.1. 
Table 10.1 Sample distribution by institution

\begin{tabular}{|l|r|r|}
\hline Type of institution & Number & Share (\%) \\
\hline Big four state-owned banks & 315 & 38.70 \\
\hline Equity banks & 160 & 19.60 \\
\hline Postal savings banks & 84 & 10.30 \\
\hline City commercial banks & 105 & 12.90 \\
\hline Rural commercial banks & 50 & 6.10 \\
\hline Rural credit cooperatives & 44 & 5.40 \\
\hline Village banks & 47 & 5.80 \\
\hline Foreign banks & 10 & 1.20 \\
\hline Total & 815 & 100.00 \\
\hline
\end{tabular}

Source: Authors' calculations using FEES.

The survey data are rich in detail, containing not only detailed financial information, such as balance sheet and bank credit outcomes, but also nonfinancial variables, such as evaluations of the SME loans ratio and basic information about financial institutions.

The data provide us with information on whether and when an institution started to evaluate its share of SME loans, the specific requirements and whether the branch met those requirements. Excluding financial institutions that did not report information on SME loan evaluations, we obtain a panel dataset spanning 2005 to 2013, for 756 institutions.

\section{Summary statistics of SME financing schemes at bank level}

The key variable of this study is whether and when a bank begins to implement evaluation of SME loan shares. Table 10.2 provides an illustration of the evaluation of SME loan shares for the surveyed institutions. In total, 446 of the total 756 financial institutions surveyed implemented an evaluation of SME loan shares during our sample period (see Column 1 in Table 10.2), accounting for 58.99 per cent (Column 2 in Table 10.2).

Among the institutions that implemented such an evaluation, only 34 (7.62 per cent) provided the SME loan evaluation before 2008, with the majority (92.38 per cent) beginning to adopt this evaluation in 2008 or after (see Column 3 in Table 10.2). Since 2008, there have been 68 institutions, on average, adopting this evaluation each year, with a peak in 2010 of 103 institutions. The data also show that the initial year of evaluation of SME loans was centred on the period between 2008 and 2014. This is mainly due to the exogenous shock of the new CBRC regulations from 2008. During our sample period (2005-13), 438 branches implemented the evaluation of SME loans, accounting for 57.94 per cent of the total sample. 
Table 10.2 Number of branches starting to evaluate SME loans, by year

\begin{tabular}{|l|r|r|r|}
\hline Initial year of evaluation & \multicolumn{1}{|c|}{$\begin{array}{c}\text { (1) } \\
\text { No. of } \\
\text { branches }\end{array}$} & $\begin{array}{c}\text { (2) } \\
\text { Share of branches } \\
\text { adopting evaluation (100\%) }\end{array}$ & $\begin{array}{c}\text { (3) } \\
\text { Share of initial } \\
\text { year (100\%) }\end{array}$ \\
\hline 1986 & 1 & 0.13 & 0.22 \\
\hline 1990 & 1 & 0.13 & 0.22 \\
\hline 2001 & 1 & 0.13 & 0.22 \\
\hline 2002 & 1 & 0.13 & 0.22 \\
\hline 2003 & 2 & 0.26 & 0.45 \\
\hline 2004 & 1 & 0.13 & 0.22 \\
\hline 2005 & 6 & 0.79 & 1.35 \\
\hline 2006 & 4 & 0.53 & 0.90 \\
\hline 2007 & 17 & 2.25 & 3.81 \\
\hline 2008 & 28 & 2.25 & 6.28 \\
\hline 2009 & 49 & 3.70 & 10.99 \\
\hline 2010 & 103 & 6.48 & 23.09 \\
\hline 2011 & 80 & 13.62 & 17.94 \\
\hline 2012 & 92 & 10.58 & 20.63 \\
\hline 2013 & 59 & 12.17 & 13.23 \\
\hline 2014 & 1 & 7.80 & 0.22 \\
\hline Before 2008 & 34 & 4.50 & 7.62 \\
\hline After 2007 & 412 & 54.49 & 92.38 \\
\hline Total & 446 & 58.99 & 100 \\
\hline
\end{tabular}

Source: Authors' calculation using FEES.

In terms of the different categories of commercial banks, the proportion of domestic commercial banks adopting evaluation of SME loans is much higher than that of foreign banks (see Table 10.3). The ratios of the city commercial banks, the big four state-owned banks and rural commercial banks are significantly higher than the sample average, while those of rural credit cooperatives and postal savings banks are significantly below the sample average.

For those institutions that evaluate SME loans, the requirements on the SME loans share are obviously different, as shown in Figure 10.1. The share of SME loans is required to be above or close to 50 per cent for village banks, foreign banks, city commercial banks and rural commercial banks, while it is required to be about 30 per cent for equity banks, rural credit cooperatives, the big four state-owned banks and postal savings banks. 
Table 10.3 Number of branches starting to evaluate SME loans, by institution type

\begin{tabular}{|l|r|r|r|r|r|r|}
\hline Type & $\begin{array}{c}\text { Before } \\
2008\end{array}$ & 2008-13 & Total & $\begin{array}{c}\text { Total } \\
\text { sample }\end{array}$ & Ratio (\%) & Rank \\
\hline Big four state-owned banks & 24 & 170 & 194 & 297 & 65.32 & 2 \\
\hline Equity banks & 5 & 74 & 79 & 142 & 55.63 & 5 \\
\hline Postal savings banks & 4 & 28 & 32 & 80 & 40 & 6 \\
\hline City commercial banks & 1 & 67 & 68 & 97 & 70.10 & 1 \\
\hline Rural commercial banks & & 29 & 29 & 45 & 64.44 & 3 \\
\hline Rural credit cooperatives & & 14 & 14 & 40 & 35 & 7 \\
\hline Village banks & & 27 & 27 & 45 & 60 & 4 \\
\hline Foreign banks & & 2 & 2 & 10 & 20 & 8 \\
\hline
\end{tabular}

Source: Authors' calculations using FEES.

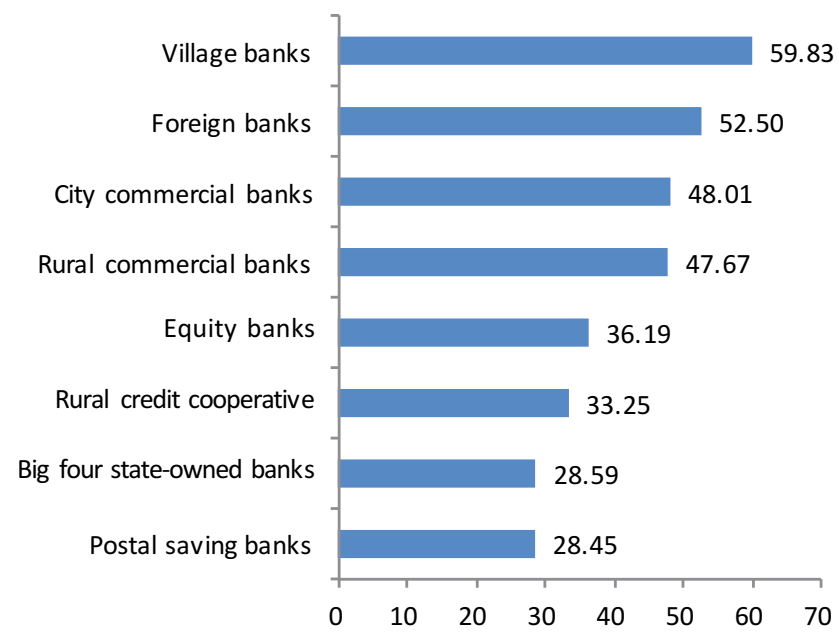

Figure 10.1 The lower bound requirement for SME loan shares for reformed branches (per cent)

Source: Authors' calculations using FEES.

Since the evaluation on SME loan shares was introduced, the proportion of branches that do not meet the evaluation requirements has significantly decreased across all institutions-from 90.71 per cent to 46.38 per cent, on average, as indicated in the last row of Table 10.4. This reduction is almost 40 per cent for all types of institutions, except for the postal savings banks. The postal savings banks managed a reduction of only 24.2 per cent, while they had the highest proportion of branches among the domestic banks falling short of the evaluation requirements both before and after evaluations began. Overall, Table 10.4 indicates that the evaluation of SME loan shares has a strong effect in increasing SME loans, while it was challenging for the postal savings banks to meet the evaluation requirements during our sample period. 
Table 10.4 The proportion of branches not meeting the evaluation requirements for SME loan shares, by institution

\begin{tabular}{|l|r|r|r|r|}
\hline Type of institution & $\begin{array}{c}\text { Before } \\
\text { evaluation (\%) }\end{array}$ & $\begin{array}{c}\text { Since } \\
\text { evaluation (\%) }\end{array}$ & Difference (\%) & Rank \\
\hline Big four state-owned banks & 81.63 & 41.88 & 39.75 & 7 \\
\hline Equity banks & 97.79 & 51.90 & 45.89 & 2 \\
\hline Postal savings banks & 99.20 & 75.00 & 24.20 & 8 \\
\hline City commercial banks & 91.55 & 45.93 & 45.62 & 3 \\
\hline Rural commercial banks & 85.99 & 43.96 & 42.03 & 5 \\
\hline Rural credit cooperatives & 87.64 & 38.82 & 48.82 & 1 \\
\hline Village banks & 97.95 & 52.38 & 45.57 & 4 \\
\hline Foreign banks & 100.00 & 60.00 & 40.00 & 6 \\
\hline Total & 90.71 & 46.38 & 44.33 & \\
\hline
\end{tabular}

Source: Authors' calculations using FEES.

In summary, there are differences in whether and when different types of financial institutions implemented evaluations of SME loan shares. The staggered adoption of the evaluations provides rich variation with which to identify its effects on SME loans as well as on other bank lending outcomes.

\section{Do SME financing schemes increase loans to SMEs?}

\section{Empirical model specification}

We begin our analysis by examining whether the evaluation of SME loan shares effectively increases lending to SMEs. To identify the effect of SME financing schemes on the origination of bank loans to SMEs, we employ a difference-indifferences (DID) strategy and compare a group of financial institutions before and after they adopted the evaluations with those institutions that had not yet adopted it during the same period. Thus, the baseline empirical specification is given by Equation 10.1.

\section{Equation 10.1}

$S M E$ loan $_{i t}=\beta_{0}+\beta_{1}$ Evaluation $_{i t}+\beta_{2} X_{i t}+v_{i}+\tau_{t}+\varepsilon_{i t}$

In this equation, $i, c$ and $t$ indicate bank, county and year, respectively.

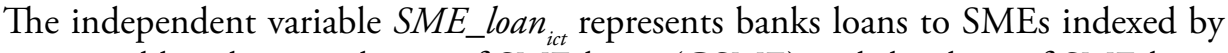
two variables: the growth rate of SME loans (GSME) and the share of SME loans (SME). Evaluation is the regressor of interest, standing for the incentive design of 
bank $i$ in year $t$. Specifically, Evaluation $n_{i t}=$ Treatment $_{i} \cdot$ Post $_{i t}$, where Treatment $_{i}=1$ if bank $i$ carried out the SME scheme during the sample period, and 0 otherwise. Post $_{i t}=1$ is a post-treatment indictor, taking a value of 1 if $t \geq \operatorname{tc} 0$, where tc 0 is the year bank $i$ implements the evaluation, and 0 otherwise.

$X_{i t}$ represents other important bank-level variables that may affect banks' loan allocations. In the baseline model, we include bank size, indexed by the logarithm of total assets (Lnassets). The bank fixed effects $\left(v_{i}\right)$ capture all the time-invariant bank characteristics that might influence the outcome of interest. Year fixed effects $\left(\tau_{t}\right)$ control for nationwide shocks in a particular year that are likely to have affected all banks in a similar manner. $\varepsilon_{i t}$ is the error term. To address the potential serial correlation and heteroskedasticity, we cluster the standard errors at the county level. Detailed variable definitions and descriptive statistics are presented in Table 10.5.

This strategy identifies how the evaluations of SME loans affect bank loans to SMEs, controlling for other important influencing variables and time and bank-invariant effects. The coefficient $\beta_{1}$ is our DID estimate of the effect of interest.

Table 10.5 Variable definitions and summary statistics

\begin{tabular}{|l|l|r|r|r|r|r|r|}
\hline Variable & Definition & \multicolumn{1}{c|}{ Obs } & \multicolumn{1}{c|}{ Mean } & \multicolumn{1}{c|}{ SD } & \multicolumn{1}{c|}{ p50 } & \multicolumn{1}{c|}{ Min. } & \multicolumn{1}{c|}{ Max. } \\
\hline GSME & $\begin{array}{l}\text { Growth rate of SME } \\
\text { loans (\%) }\end{array}$ & 2,233 & 0.101 & 0.2279 & 0 & -1 & 1.189 \\
\hline SME & SME loan share (\%) & 2,981 & 71.530 & 37.0740 & 95.700 & 0 & 100.000 \\
\hline NPLR & $\begin{array}{l}\text { Nonperforming loans } \\
\text { ratio (\%) }\end{array}$ & 1,691 & 2.576 & 4.6790 & 0.632 & 0 & 26.130 \\
\hline Lnasset & $\begin{array}{l}\text { Logarithm of total } \\
\text { assets }\end{array}$ & 2,981 & 12.118 & 1.2280 & 12.054 & 5.995 & 16.750 \\
\hline ROA & Return over total assets & 2,981 & 0.019 & 0.0260 & 0.018 & -0.364 & 0.857 \\
\hline NII & $\begin{array}{l}\text { Net interest rate } \\
\text { income over total loan } \\
\text { outstanding }\end{array}$ & 2,880 & 0.075 & 0.3320 & 0.048 & -1.365 & 10.530 \\
\hline
\end{tabular}

For the banks that implemented the evaluation of SME loan shares in 2005 and previous years, it is impossible to obtain the comparison data for the pre-treatment period. For the banks that implemented evaluations in 2013, it is impossible to obtain the comparison data for the post-treatment period. We therefore remove these banks to allow at least one year before and one year after the evaluation adoption, as required by the DID method. 


\section{Empirical results}

Table 10.6 reports the baseline results of the impact of the evaluation of SME loans on banks' credit allocation to SMEs. Column (1) shows the results of how implementing the evaluation impacts the growth rate of SME loans and it shows an insignificant effect. Column (3) examines the impacts of the evaluation on the share of SME loans in total loans outstanding, and the effect of the evaluation is still insignificant. Therefore, on average, it seems that the evaluation is ineffective in enhancing banks' loan originations to SMEs.

Table 10.6 Impacts of evaluation of SME loans: Total effect

\begin{tabular}{|l|r|r|r|r|}
\hline \multirow{2}{*}{ Variables } & \multicolumn{1}{c|}{$(1)$} & \multicolumn{1}{c|}{$(2)$} & \multicolumn{1}{c|}{$(3)$} & \multicolumn{1}{c|}{$(4)$} \\
\hline \multirow{2}{*}{ Evaluation } & \multicolumn{1}{|c|}{ Growth rate of SME loans } & \multicolumn{2}{c|}{ Share of SME loans } \\
\cline { 2 - 6 } & 0.1160 & 0.1073 & 1.6334 & 1.1839 \\
\cline { 2 - 6 } & $(0.0990)$ & $(0.1349)$ & $(1.0258)$ & $(1.2918)$ \\
\cline { 2 - 6 } & $-0.0259^{\star * \star}$ & $-0.0280^{\star \star \star}$ & $0.5258^{\star \star \star}$ & $0.4957^{\star \star \star}$ \\
\hline \multirow{2}{*}{ Inasset } & $(0.0029)$ & $(0.0037)$ & $(0.0178)$ & $(0.0214)$ \\
\cline { 2 - 6 } & 0.0003 & -0.0136 & -1.1115 & -0.5041 \\
\hline Year effect & $(0.1393)$ & $(0.1986)$ & $(1.3093)$ & $(1.6527)$ \\
\hline Institute ${ }^{\star}$ Year & YES & NO & YES & NO \\
\hline Province ${ }^{\star}$ Year & NO & YES & NO & YES \\
\hline Branch FE & NO & YES & NO & YES \\
\hline Constant & YES & YES & YES & YES \\
\hline Observations & YES & YES & YES & YES \\
\hline R-squared & 2,227 & 1,776 & 2,451 & 1,992 \\
\hline
\end{tabular}

${ }^{* \star *} p<0.01{ }^{* \star} p<0.05 * p<0.1$

Note: Standard errors are in parentheses.

Source: Authors' estimations.

One concern with the above models might be that some local credit demand shocks and institutional credit supply shocks (such as policy and technology shocks) might coincide with the banks' adoption of the evaluation. To account for this and other similar concerns, in Columns (2) and (4), we modify the model by including an interacted year with province fixed effects and an interacted year with legal institutional fixed effects. This specification controls for all time variations within those provinces and within those legal institutions. In such a specification, one compares the growth rate of SME loans and SME loan shares of a bank adopting evaluation with a bank of the same legal institution not adopting it in the same province and in the same year. As a result, we exploit the intraprovincial and intralegal institutional variations between treated and non-treated branches. To the extent that local shocks affect all banks at a provincial level and internal shocks 
affect all branches of the same legal institution, such shocks are differenced out in our specification. Columns (2) and (4) indicate an insignificant impact from the evaluation on both the growth rate of SME loans and the share of SME loans.

As elaborated in the previous section, before implementing the evaluation, some banks had already met the requirements, although most had not. Banks that met the requirements before implementing the evaluation did not need to increase their loans to SMEs following implementation. Therefore, the estimations in Table 10.6 may underestimate the effect of evaluation as they mix all the treated banks in the same way. In this regard, we modify the model by distinguishing between the initial conditions of banks in terms of whether they meet the evaluation requirements. The results for how implementing evaluation of SME loan shares affects the growth rate of SME loans are presented in Table 10.7 and the impacts on the shares of SME loans are presented in Table 10.8 .

In the first columns of Table 10.7, we include the interaction of the variable Evaluation with the lag term of the share of SME loans (L.SME). This shows a significantly positive effect of the evaluation and a significantly negative effect of its interaction with the lag term of the share of SME loans. This indicates that implementing the evaluation increases the growth rate of SME loans, while this effect weakens as the initial share of SME loans increases. The results imply that the initial conditions when implementing evaluation are important in determining its overall effectiveness. As the initial SME loans share is low, the effect of the evaluation in enhancing loans to SMEs is strong. The results are robust in the model of Column (2), as shocks from the region and legal institutions are controlled.

Furthermore, we identify whether the initial SME loans share meets the evaluation requirements and construct a dummy variable, below, to indicate the initial conditions. If the initial SME loans share is below the evaluation requirement, below equals 1 and we call these 'constrained' banks; otherwise, it equals 0 , and these banks are 'unconstrained'. We then include both the variable below and its interaction with the evaluation in Column (3). The results indicate significantly positive effects from both the interaction term and the variable of initial conditions (L.Below), and positive but insignificant effects of the variable Evaluation. For the unconstrained banks, the evaluation has no significant effect on the growth rate of SME loans. For the constrained banks, the effect of the evaluation is determined by both the coefficients of Evaluation and the interaction term (Evaluation* L.Below). The overall effect of evaluation for these banks is significant, around 0.37 per cent, which implies that, after evaluation, the growth rate of SME loans increases by 0.37 per cent, on average. As the sample mean of the growth rate is 0.101 per cent, this overall effect of 0.37 per cent is comparably very strong. The modified model specification in Column (4) does not affect the qualitative nature of our results other than a slightly increased overall effect for the constrained banks. 
Table 10.7 Impacts of evaluation on the growth rate of SME loans

\begin{tabular}{|c|c|c|c|c|}
\hline & (1) & (2) & (3) & (4) \\
\hline Variables & \multicolumn{2}{|c|}{ Growth rate of SME loans } & & \\
\hline \multirow[t]{2}{*}{ Evaluation } & $0.6204^{\star \star \star}$ & $0.6384^{\star \star}$ & 0.0453 & 0.0472 \\
\hline & $(0.2190)$ & $(0.2834)$ & $(0.1123)$ & $(0.0761)$ \\
\hline \multirow[t]{2}{*}{ L.SME } & $-0.0239^{\star \star \star}$ & $-0.0260^{\star \star \star}$ & & \\
\hline & $(0.0030)$ & $(0.0038)$ & & \\
\hline \multirow[t]{2}{*}{ Evaluation*L.SME } & $-0.0064^{\star \star \star}$ & $-0.0070^{\star \star}$ & & \\
\hline & $(0.0025)$ & $(0.0033)$ & & \\
\hline \multirow[t]{2}{*}{ Evaluation*L.Below } & & & $0.3276^{\star}$ & $0.3641^{\star \star \star}$ \\
\hline & & & $(0.1816)$ & $(0.1203)$ \\
\hline \multirow[t]{2}{*}{ L.Below } & & & $1.0346^{\star \star \star}$ & $1.2209^{\star \star}$ \\
\hline & & & $(0.2487)$ & $(0.5866)$ \\
\hline \multirow[t]{2}{*}{ Lnasset } & 0.0366 & 0.0096 & 0.0038 & -0.0201 \\
\hline & $(0.1398)$ & $(0.1986)$ & $(0.1413)$ & $(0.1163)$ \\
\hline Year effect & YES & $\mathrm{NO}$ & YES & NO \\
\hline Institute ${ }^{\star}$ Year & $\mathrm{NO}$ & YES & $\mathrm{NO}$ & YES \\
\hline Province* Year & $\mathrm{NO}$ & YES & $\mathrm{NO}$ & YES \\
\hline Branch FE & YES & YES & YES & YES \\
\hline Constant & YES & YES & YES & YES \\
\hline Observations & 2,227 & 1,776 & 2,227 & 1,776 \\
\hline R-squared & 0.2448 & 0.3485 & 0.2226 & 0.3309 \\
\hline Overall effect when below & & & $0.3729^{\star \star}$ & $0.4113^{\star \star \star}$ \\
\hline Standard error & & & 0.1653 & 0.0761 \\
\hline
\end{tabular}

${ }^{* * *} \mathrm{p}<0.01^{* \star} \mathrm{p}<0.05^{*} \mathrm{p}<0.1$

Note: Standard errors are in parentheses.

Source: Authors' estimations.

In Table 10.8, we investigate how the evaluation affects banks' shares of SME loans. Results in the first two columns show robust evidence that the evaluation significantly increases the share of banks' SME loans, and this effect is stronger for banks with higher initial shares of SME loans. In Columns (3) and (4), the coefficient of Evaluation is significantly negative while the interaction term (Evaluation ${ }^{*} L$. Below) is significantly positive. This reveals that, for banks with an initial share of SME loans above the requirement, their share of SME loans falls significantly-by more than 4 per cent. But for banks with an initial share of SME loans below the requirement, the share of SME loans increases by more than 6 per cent. 
Table 10.8 Impacts of evaluation on the share of SME loans

\begin{tabular}{|c|c|c|c|c|}
\hline \multirow[t]{2}{*}{ Variables } & (1) & $(2)$ & (3) & (4) \\
\hline & \multicolumn{4}{|c|}{ Share of SME loans } \\
\hline \multirow[t]{2}{*}{ Evaluation } & $10.5757^{\star \star \star}$ & $6.8199^{\star \star \star}$ & $-4.5368^{\star * \star}$ & $-4.2711^{\star \star \star}$ \\
\hline & $(1.8290)$ & $(2.2015)$ & $(1.4100)$ & $(1.6123)$ \\
\hline \multirow[t]{2}{*}{ L.SME } & $0.5543^{\star * \star}$ & $0.5142^{\star \star \star}$ & & \\
\hline & $(0.0183)$ & $(0.0221)$ & & \\
\hline \multirow[t]{2}{*}{ Evaluation*L.SME } & $-0.1245^{\star \star \star}$ & $-0.0826^{\star \star \star}$ & & \\
\hline & $(0.0212)$ & $(0.0262)$ & & \\
\hline \multirow[t]{2}{*}{ Evaluation^L.Below } & & & $11.7152^{\star \star \star}$ & $10.3552^{\star \star \star}$ \\
\hline & & & $(1.8777)$ & $(2.6879)$ \\
\hline \multirow[t]{2}{*}{ L.Below } & & & $-16.4225^{\star \star \star}$ & $-20.7308^{\star \star \star}$ \\
\hline & & & $(1.8551)$ & (3.6403) \\
\hline \multirow[t]{2}{*}{ Lnasset } & -0.8912 & -0.6454 & 0.1271 & -1.1991 \\
\hline & $(1.2990)$ & $(1.6482)$ & $(1.3871)$ & $(2.9591)$ \\
\hline Year effect & YES & NO & YES & NO \\
\hline Institute*Year & $\mathrm{NO}$ & YES & $\mathrm{NO}$ & YES \\
\hline Province*Year & $\mathrm{NO}$ & YES & $\mathrm{NO}$ & YES \\
\hline Branch FE & YES & YES & YES & YES \\
\hline Constant & YES & YES & YES & YES \\
\hline Observations & 2,451 & 1,992 & 2,805 & 2,248 \\
\hline R-squared & 0.9050 & 0.9110 & 0.8589 & 0.8788 \\
\hline Overall effect when below & & & $7.1783^{\star \star \star}$ & $6.08407^{* *}$ \\
\hline Standard error & & & 1.5988 & 2.4405 \\
\hline
\end{tabular}

${ }^{\star * *} p<0.01^{* *} p<0.05^{*} p<0.1$

Note: Standard errors are in parentheses.

Source: Authors' estimations.

In Table 10.9, we further check the effects of the evaluation on banks of different size. We classify the big four state-owned banks and the national equity banks as large banks and the remainder as small banks. Results in Table 10.9 show that the evaluation has no effect on the unconstrained small banks while it significantly decreases the share of SME loans for the unconstrained large banks. For the constrained banks, the evaluation significantly increased the share of SME loans for both small and large banks, with a slightly larger effect for small banks than for larger banks. These results indicate that the evaluation effectively promotes the constrained banks to allocate more loans to SMEs. 
Table 10.9 Impacts of evaluation on the share of SME loans, by bank size

\begin{tabular}{|c|c|c|c|c|}
\hline \multirow[t]{3}{*}{ Variables } & (1) & $(2)$ & (3) & (4) \\
\hline & \multicolumn{4}{|c|}{ Share of SME loans } \\
\hline & Small banks & Large banks & Small banks & Large banks \\
\hline \multirow[t]{2}{*}{ Evaluation } & -0.9499 & $-4.6540^{\star \star \star}$ & 1.0763 & $-4.9057^{\text {*** }}$ \\
\hline & $(1.9064)$ & $(1.6226)$ & $(1.8447)$ & $(1.6550)$ \\
\hline \multirow[t]{2}{*}{ Evaluation*L.Below } & $8.7482^{\star \star \star}$ & $10.7829^{\star \star \star}$ & $6.9654^{*}$ & $10.4752^{\star \star \star}$ \\
\hline & $(2.6435)$ & $(2.1694)$ & $(3.9017)$ & $(2.7140)$ \\
\hline \multirow[t]{2}{*}{ L.Below } & $-5.8593^{\star \star \star}$ & $-21.6008^{\star \star \star}$ & -3.2827 & $-22.1151^{\star \star \star}$ \\
\hline & $(2.2509)$ & $(2.3042)$ & $(3.6485)$ & (3.9876) \\
\hline \multirow[t]{2}{*}{ Inasset } & $5.8558^{\star \star \star}$ & -1.7280 & $9.4113^{*}$ & -0.8208 \\
\hline & $(2.2316)$ & $(1.6415)$ & $(5.3561)$ & (3.3182) \\
\hline Year effect & YES & YES & $\mathrm{NO}$ & $\mathrm{NO}$ \\
\hline Institute Year & $\mathrm{NO}$ & $\mathrm{NO}$ & YES & YES \\
\hline Province* Year & $\mathrm{NO}$ & $\mathrm{NO}$ & YES & YES \\
\hline Branch FE & YES & YES & YES & YES \\
\hline Constant & YES & YES & YES & YES \\
\hline Observations & 732 & 1,903 & 755 & 1,926 \\
\hline R-squared & 0.8698 & 0.8666 & 0.8959 & 0.8885 \\
\hline Overall effect when below & $7.7983^{\star \star \star}$ & $6.1288^{\star \star \star}$ & $8.041733^{\star *}$ & $5.5696^{\star \star}$ \\
\hline Standard error & 2.3436 & 1.8528 & 3.901827 & 2.372877 \\
\hline
\end{tabular}

${ }^{* * *} \mathrm{p}<0.01{ }^{* *} \mathrm{p}<0.05{ }^{*} \mathrm{p}<0.1$

Note: Standard errors are in parentheses.

Combining the results in Tables 10.7-10.9, we find that implementing evaluation of SME loans has increased banks' loan originations to SMEs, especially for banks that have low shares of SME loans. In this regard, the evaluation is effective and beneficial.

\section{How do SME financing schemes affect banks' credit risk?}

So far, we have shown that evaluation of SME loans effectively increases the number of loans to SMEs. But usually more serious information asymmetry between banks and SMEs results in higher credit risk for SME loans (Stiglitz and Weiss 1981). To assess the overall influence of this evaluation of SME loans on banks, we go further to investigate the impact of the evaluation on banks' credit risk in Equation 10.2, with the DID strategy. 


\section{Equation 10.2}

$$
\begin{aligned}
N_{P L R} & =\alpha_{0}+\alpha_{1} \text { Evaluation }_{i t}+\alpha_{2} \text { Evaluation }_{i t} * \text { L.Below } \\
& +\alpha_{3} X_{i t}+v_{i}+\tau_{t}+\varepsilon_{i t}
\end{aligned}
$$

In Equation 10.2, credit risk is measured by NPLR, following Zhang et al. (2016) and subject to data availability. We control bank size, the SME loan ratio, timeinvariant fixed effects and bank-invariant fixed effects. The baseline results are presented in Table 10.10 .

The results in Column (1) show a significant and negative effect of Evaluation on the NPLR, and the interaction term (Evaluation ${ }^{*}$ L.Below) is robustly significant and positive. These results indicate that, for banks with an initial share of SME loans at or above the requirements (unconstrained banks), the evaluation decreases their NPLR.

However, these results imply that for banks with an initial share of SME loans below the evaluation requirement (constrained banks), their NPLR increases by 0.23 per cent $(-1.0971$ per cent +1.3265 per cent) following the evaluation. This overall effect is not significant. Results are robust, as we control for regional and legal institutional shocks in Column (2).

We believe there is a competition effect between the unconstrained and constrained banks, which may help explain the above findings. The unconstrained banks face no pressure to increase their SME loans and have the space to increase non-SME loans. Meanwhile, restrained by both the regulated requirements for SME loans and lending capacity, the constrained banks move partly to the SME loans market, which increases competition in that market and decreases competition in the nonSME loans market. The reduction of competition in the non-SME loans market facilitates the unconstrained banks decreasing their NPLR. The constrained banks struggle to expand their loans to SMEs, which puts them into the more competitive and higher-risk SME market.

In Columns (3) and (4) of Table 10.10, we further check the heterogeneous effect of the evaluation on credit risk for small and large banks. Results indicate significantly negative effects of Evaluation and positive effects of the interaction term (Evaluation* ${ }^{*}$. Below) for both small banks and large banks, except that the coefficient of Evaluation is insignificant for small banks.

For the unconstrained banks, the evaluation has no significant effect on small banks' NPLR, while it significantly decreases the NPLR of large banks. For the constrained large banks, the overall effect of the evaluation on NPLR is 0.18 per cent ( 1.4123 per cent -1.2370 per cent) but is insignificant. However, it is significant and about 2.1 per cent $(2.2593$ per cent -0.1726 per cent) for 
the constrained small banks. These findings imply that the SME loans requirement significantly exacerbates the credit risk of constrained small banks while it improves the credit quality of unconstrained large banks.

There are two possible interpretations that may help explain the above results. On the one hand, there is another competition effect, which is between small banks and large banks. Although small banks usually have a greater advantage in providing loans to SMEs (Berger and Udell 2006), they suffer from more severe competition from large banks after the policy shock. Under the policy shocks of the CBRC's regulations on SME loans, large banks start to compete more in the SME loans market, which crowds out some high-quality SMEs to large banks from small banks and then worsens the credit quality for small banks. On the other hand, large banks have greater diversification opportunities and higher levels of management of credit risk.

Table 10.10 Impacts of evaluation on branches' nonperforming loans

\begin{tabular}{|c|c|c|c|c|}
\hline \multirow[t]{2}{*}{ Variables } & $\begin{array}{c}(1) \\
\text { NPLR }\end{array}$ & $\begin{array}{c}(2) \\
\text { NPLR } \\
\end{array}$ & $\begin{array}{c}(3) \\
\text { NPLR } \\
\end{array}$ & $\begin{array}{c}(4) \\
\text { NPLR } \\
\end{array}$ \\
\hline & Whole sample & Whole sample & Small bank & Large bank \\
\hline \multirow[t]{2}{*}{ Evaluation } & $-1.0971^{\star *}$ & $-1.3347^{\star \star \star}$ & -0.1726 & $-1.2370^{\prime}$ \\
\hline & $(0.5236)$ & $(0.2770)$ & $(0.1109)$ & $(0.5979$ \\
\hline \multirow[t]{2}{*}{ Evaluation*L.Below } & $1.3265^{*}$ & $1.4569^{\star \star \star}$ & $2.2593^{\star * \star}$ & 1.4123 \\
\hline & $(0.7162)$ & $(0.3924)$ & $(0.4128)$ & $(0.7065)$ \\
\hline \multirow[t]{2}{*}{ L.Below } & -0.7779 & $-1.3898^{\star \star \star}$ & $-2.2313^{\star \star \star}$ & -1.0286 \\
\hline & $(0.7902)$ & $(0.2297)$ & $(0.0109)$ & $(0.5856)$ \\
\hline \multirow[t]{2}{*}{ SME } & 0.0136 & 0.0102 & -0.0063 & 0.0157 \\
\hline & $(0.0099)$ & $(0.0082)$ & $(0.0042)$ & $(0.0124)$ \\
\hline \multirow[t]{2}{*}{ Inasset } & -0.9489 & 0.6479 & -2.6830 & 1.2713 \\
\hline & $(0.8013)$ & $(0.7671)$ & $(2.6271)$ & $(1.1394)$ \\
\hline Year & YES & $\mathrm{NO}$ & $\mathrm{NO}$ & $\mathrm{NO}$ \\
\hline Institute*Year & $\mathrm{NO}$ & YES & YES & $\mathrm{NO}$ \\
\hline Province* Year & $\mathrm{NO}$ & YES & YES & $\mathrm{NO}$ \\
\hline Branch FE & YES & YES & YES & YES \\
\hline Observations & 1,800 & 1,800 & 468 & 1,361 \\
\hline R-squared & 0.6255 & 0.9246 & 0.9972 & 0.7981 \\
\hline Overall effect when below & 0.2295 & 0.1222 & $2.0867^{\star \star \star}$ & 0.1753 \\
\hline Standard error & 0.4139 & 0.2209 & 0.3464 & 0.1753 \\
\hline
\end{tabular}

*** $p<0.01{ }^{* *} p<0.05^{*} p<0.1$

Note: Standard errors are in parentheses.

Source: Authors' estimations. 
To combine results in the previous section, our findings highlight that the evaluation of SME loans is a double-edged sword for the constrained banks: although it pushes these banks to expand their SME loans, it also brings higher credit risk to small banks. Banks that increase their loans to SMEs incur a cost by bearing more credit risk, especially small banks.

\section{How do SME financing schemes affect banks' profits?}

To complete the picture, we also check how the evaluation of SME loans affects banks' profits. The empirical specification is given by Equation 10.3.

Equation 10.3

$$
\begin{aligned}
\text { Profits }_{i t} & =\gamma_{0}+\gamma_{1} \text { Evaluation }_{i t}+\gamma_{2} \text { Evaluation }_{i t} * \text { L.Below } \\
& +\gamma_{3} X_{i t}+v_{i}+\tau_{t}+\zeta_{i t}
\end{aligned}
$$

We measure banks' profits with two variables: net interest rate income over total loans outstanding (NII) and the return on assets (ROA). The former variable indicates banks' profitability on the business of deposits and loans, and the latter represents banks' overall profitability.

Table 10.11 reports the impacts of the evaluation on net interest income and returns over bank assets. The results of Columns (1) and (2) show that the coefficient of Evaluation is significantly positive and the coefficient of the interaction term (Evaluation ${ }^{*}$ L.Below) is significantly negative. These results imply that, for unconstrained banks, the evaluation improves their net interest income. For banks that are constrained by the evaluation requirements, the evaluation has an overall negative influence on their net interest income, but it is not significant.

For Columns (3) and (4), results are similar. While evaluation increases the return on assets for unconstrained banks, it has a negative but insignificant impact on the constrained banks that fell short of the requirements before the evaluation. 
Table 10.11 Impacts of evaluation on branches' performance

\begin{tabular}{|c|c|c|c|c|}
\hline Variables & $\begin{array}{l}(1) \\
\text { NII }\end{array}$ & $\begin{array}{l}(2) \\
\text { NII }\end{array}$ & $\begin{array}{c}(3) \\
\mathrm{ROA}\end{array}$ & $\begin{array}{c}(4) \\
\mathrm{ROA}\end{array}$ \\
\hline \multirow[t]{2}{*}{ Evaluation } & $0.0097^{\star \star \star}$ & $0.0057^{\star \star \star}$ & $0.0040^{* \star \star}$ & $0.0045^{\star * \star}$ \\
\hline & $(0.0033)$ & $(0.0018)$ & $(0.0011)$ & $(0.0010)$ \\
\hline \multirow[t]{2}{*}{ Evaluation*L.Below } & $-0.0161^{\star \star \star}$ & $-0.0097^{*}$ & $-0.0056^{\star \star \star}$ & $-0.0047^{\star \star}$ \\
\hline & $(0.0047)$ & $(0.0051)$ & $(0.0014)$ & $(0.0017)$ \\
\hline \multirow[t]{2}{*}{ L.Below } & $0.0111^{\star \star \star}$ & $0.0091^{\star *}$ & $0.0039^{\star \star \star}$ & $0.0033^{\star * *}$ \\
\hline & $(0.0032)$ & $(0.0045)$ & $(0.0011)$ & $(0.0006)$ \\
\hline \multirow[t]{2}{*}{ Lnasset } & 0.0017 & 0.0003 & -0.0018 & $-0.0041^{\text {*x }}$ \\
\hline & $(0.0060)$ & $(0.0057)$ & $(0.0015)$ & $(0.0017)$ \\
\hline Year & YES & $\mathrm{NO}$ & YES & $\mathrm{NO}$ \\
\hline Institute*Year & $\mathrm{NO}$ & YES & NO & YES \\
\hline Province*Year & $\mathrm{NO}$ & YES & $\mathrm{NO}$ & YES \\
\hline Branch FE & YES & YES & YES & YES \\
\hline Observations & 3,348 & 2,716 & 3,517 & 2,875 \\
\hline R-squared & 0.7597 & 0.8097 & 0.7157 & 0.7865 \\
\hline Overall effect when below & -0.0064 & -0.004 & -0.0016 & -0.0003 \\
\hline Standard error & 0.0040 & 0.0044 & 0.0010 & 0.0012 \\
\hline
\end{tabular}

*** $p<0.01^{* \star} p<0.05^{*} p<0.1$

Note: Standard errors are in parentheses.

Source: Authors' estimations.

We then go through the different effects of the evaluation on the profitability of small and large banks in Table 10.12. Interestingly, we find that the evaluation significantly increases profits for unconstrained large banks, while it has no effect on unconstrained small banks. This also relates to the two competition effects between constrained and unconstrained banks and between constrained small and constrained large banks. The unconstrained large banks improve their profitability as they do not have to compete for SME loans, but they enjoy less competitive non-SME loans. For the unconstrained small banks, they face more severe competition in the SME loans market and meanwhile have more space to provide services to non-SME loans. Therefore, the overall effect of the evaluation on these small unconstrained banks is ambiguous, and it is insignificant in our sample.

For constrained banks, the evaluation decreases net interest income for both the small and the large banks, while it decreases the return on assets for small banks only. 
Table 10.12 Impacts of evaluation on branches' performance, by bank size

\begin{tabular}{|c|c|c|c|c|}
\hline Variables & $\begin{array}{l}(1) \\
\text { NII }\end{array}$ & $\begin{array}{l}\text { (2) } \\
\text { NII }\end{array}$ & $\begin{array}{c}(3) \\
\mathrm{ROA}\end{array}$ & $\begin{array}{c}(4) \\
\text { ROA }\end{array}$ \\
\hline & Small bank & Big bank & Small bank & Big bank \\
\hline \multirow[t]{2}{*}{ Evaluation } & 0.0028 & $0.0043^{* \star}$ & 0.0002 & $0.0039^{\star \star \star}$ \\
\hline & $(0.0025)$ & $(0.0016)$ & $(0.0013)$ & $(0.0009)$ \\
\hline \multirow[t]{2}{*}{ Evaluation*L.Below } & $-0.0091^{\star \star}$ & $-0.0094^{\star \star *}$ & $-0.0032^{*}$ & $-0.0050^{\star \star \star}$ \\
\hline & $(0.0045)$ & $(0.0015)$ & $(0.0019)$ & $(0.0014)$ \\
\hline \multirow[t]{2}{*}{ L.Below } & $0.0068^{\star \star}$ & $0.0141^{\star \star \star}$ & 0.0005 & $0.0029^{\text {***}}$ \\
\hline & $(0.0032)$ & $(0.0020)$ & $(0.0016)$ & $(0.0009)$ \\
\hline \multirow[t]{2}{*}{ Lnasset } & 0.0071 & 0.0091 & 0.0044 & $-0.0056^{\star \star}$ \\
\hline & $(0.0047)$ & $(0.0055)$ & $(0.0032)$ & $(0.0020)$ \\
\hline Institute*Year & YES & YES & YES & YES \\
\hline Province*Year & YES & YES & YES & YES \\
\hline Branch FE & YES & YES & YES & YES \\
\hline Observations & 711 & 1,756 & 673 & 1,615 \\
\hline R-squared & 0.8001 & 0.7334 & 0.7243 & 0.7337 \\
\hline Overall effect when below & $-0.0054^{*}$ & $-0.0050^{*}$ & $-0.0030^{*}$ & -0.0011 \\
\hline Standard error & 0.0031 & 0.002746 & 0.0018 & 0.0012 \\
\hline
\end{tabular}

*** $p<0.01^{* *} p<0.05 * p<0.1$

Note: Standard errors are in parentheses.

Source: Authors' estimations.

\section{Benefits and costs of SME financing schemes: A summary}

In the previous three sections, we investigate the impacts of the evaluation of banks' SME loans on their lending outcomes, including banks' shares of SME loans, credit risk and profits. We summarise these effects in Table 10.13 and analyse them in the benefit and cost framework.

The expected benefit of the evaluation of the SME loans is to effectively increase the number of loans to SMEs, as the evaluation aims to boost bank loans to SMEs. But from this perspective, the overall benefit is uncertain, because the evaluation has the opposite impact on the initially unconstrained and constrained banks. It effectively increases the share of SME loans for the constrained banks, which initially fell short of the evaluation requirements, while it decreases that share for the unconstrained banks, which initially exceeded the requirements (see the first two rows of Column (1)). For banks of different size, the impacts are also different: the evaluation increases the share 
of SME loans for both constrained small and constrained large banks, but it decreases the share only for constrained large banks. Thus, overall, the evaluation increases the SME loans for small banks but the impact is unclear for large banks as a whole.

The evaluation also has some spillover effects on banks' credit risk and profits. The evaluation significantly increased the credit risk for the constrained small banks, while it decreased the credit risk for the unconstrained large banks (see the third and fourth rows of Table 10.13). While the evaluation increased profits for unconstrained large banks, it decreased profits for both small constrained and large constrained banks.

Overall, the evaluation has different influences for banks with different initial conditions regarding SME loans and banks of different size. For the constrained small banks, the evaluation increased their SME loans while raising some costs by increasing their credit risk and decreasing their profits. For the unconstrained small banks, there are no significant effects. For the constrained large banks, the evaluation increased their share of SME loans, but decreased their net interest income. The evaluation benefits the unconstrained large banks by decreasing their credit risk and improving their profits.

Table 10.13 The effect of evaluation of SME loans on banks' lending outcomes

\begin{tabular}{|c|c|c|c|c|c|}
\hline \multirow[t]{3}{*}{ Row } & \multirow[t]{3}{*}{ Lending outcome } & \multirow[t]{3}{*}{ Initial condition } & \multicolumn{3}{|c|}{ Sample } \\
\hline & & & $\begin{array}{l}\text { Whole } \\
\text { sample }\end{array}$ & $\begin{array}{l}\text { Small } \\
\text { banks }\end{array}$ & $\begin{array}{l}\text { Large } \\
\text { banks }\end{array}$ \\
\hline & & & (1) & $(2)$ & (3) \\
\hline 1 & \multirow[t]{2}{*}{ SME loans } & Unconstrained & Decrease & No & Decrease \\
\hline 2 & & Constrained & Increase & Increase & Increase \\
\hline 3 & \multirow[t]{2}{*}{ Credit risk } & Unconstrained & Decrease & No & Decrease \\
\hline 4 & & Constrained & No & Increase & No \\
\hline 5 & \multirow[t]{2}{*}{ Profits-NII } & Unconstrained & Increase & No & Increase \\
\hline 6 & & Constrained & No & Decrease & Decrease \\
\hline 7 & \multirow[t]{2}{*}{ Profits-ROA } & Unconstrained & Increase & No & Increase \\
\hline 8 & & Constrained & No & Decrease & No \\
\hline
\end{tabular}

Note: 'Decrease' and 'Increase' indicate that the evaluation significantly decreases and increases, respectively, the lending outcomes separately, and 'No' indicates that the evaluation has no significant impact on lending outcomes. 


\section{Conclusion and policy implications}

The sound development of SMEs in China is of primary importance for promoting economic growth, job creation and innovation. A lack of appropriate financing channels and credit unavailability are the main hurdles for the development of SMEs. The Chinese Government has authorised a set of schemes to solve the financing problems of SMEs. Yet, to date, there has been little evidence of the effectiveness of these schemes in increasing the number of loans to SMEs. The literature is similarly quiet on the cost to the banks of these financing schemes.

In this chapter, we investigate the benefits and costs of one of these financing schemes in China, which was initiated by the CBRC in 2008 to force commercial banks to meet certain requirements on SME loans. Based on a unique county branch-level survey dataset, our empirical analysis finds that the evaluation policy has different influences on banks with different initial conditions regarding SME loans and banks of different size. Although the evaluation policy increases lending to SMEs for banks that initially fell short of the requirements, it decreases SME loans for banks that initially exceeded the requirements. The overall benefit of this policy in terms of increasing SME loans depends on the distribution of the constrained and unconstrained banks. In regard to the cost, the evaluation increases credit risk and decreases the profits for constrained small banks, and it decreases net interest income for constrained large banks.

The empirical findings in this chapter have important policy implications. Based on our findings, financing support schemes for SMEs bring both benefits and costs for banks. One of the notable problems of this SME financing scheme is that it increases the credit risk of small banks and decreases their profits. To fix this problem, the government needs to introduce policies to fundamentally improve the business, financial and innovation environments and the service system for SMEs. The efficient enforcement of the 2018 amendments to the law on the promotion of SMEs is an important and necessary step.

\section{References}

Allen, F., Qian, J. and Qian, M. (2005), Law, finance, and economic growth in China, Journal of Financial Economics 77: 57-116. doi.org/10.1016/j.jfineco.2004.06.010.

Allen, F., Qian, J., Zhang, C. and Zhao M. (2012), China's financial system: Opportunities and challenges, NBER Working Paper No. 17828, Cambridge, MA: National Bureau of Economic Research. doi.org/10.3386/w17828.

Bai, C.E., Lu, J. and Tao, Z. (2006), Property rights protection and access to bank loans, Economics of Transition 14: 611-28. doi.org/10.1111/j.1468-0351.2006.00269.x. 
Beck, T., Demirgüç-Kunt, A. and Maksimovic, V. (2008), Financing patterns around the world: Are small firms different?, Journal of Financial Economics 89: 467-87. doi.org/ 10.1016/j.jfineco.2007.10.005.

Berger, A.N., Miller, N.H., Petersen, M.A., Rajan, R.G. and Stein, J.C. (2002), Does function follow organizational form? Evidence from the lending practices of large and small banks, NBER Working Papers No. 8752, Cambridge, MA: National Bureau of Economic Research. doi.org/10.3386/w8752.

Berger, A.N. and Udell, G.F. (1995), Relationship lending and lines of credit in small firm finance, Journal of Business 68: 351-82. doi.org/10.1086/296668.

Berger, A.N. and Udell, G.F. (1996), Universal banking and the future of small business lending, in A. Saunders and I. Walter (eds), Financial System Design: The case for universal banking, Chicago: Irwin Publishing.

Berger, A.N. and Udell, G.F. (2002), Small business credit availability and relationship lending: The importance of bank organizational structure, Economic Journal 112: 32-53. doi.org/10.1111/1468-0297.00682.

Berger, A.N. and Udell, G.F. (2006), A more complete conceptual framework for SME finance, Journal of Banking \& Finance 30(11): 2945-66. doi.org/10.1016/j.jbankfin. 2006.05.008.

Chong, T.T., Lu, L. and Ongena, S. (2013), Does banking competition alleviate or worsen credit constraints faced by small- and medium-sized enterprises? Evidence from China, Journal of Banking and Finance 37: 3412-24. doi.org/10.1016/j.jbankfin.2013.05.006.

Cole, R., Goldberg, L. and White, L. (1999), Cookie-cutter versus character: The micro structure of small business lending by large and small banks, in J. Blanton, A. Williams and S. Rhine (eds), Business Access to Capital and Credit: A Federal Reserve System research conference, Washington, DC: Board of Governors of the Federal Reserve System.

Du, J., Lu, Y. and Tao, Z. (2012), Bank loans vs. trade credit, Economics of Transition 20: 457-80. doi.org/10.1111/j.1468-0351.2012.00439.x.

Gou, Q., Huang, Y. and Xu, J. (2018), Does ownership matter in banking credit allocation in China?, European Journal of Finance 24(16): 1409-27. doi.org/10.1080/ 1351847X.2016.1190391.

Huang, Y., Cai, F., Xu, P. and Gou, Q. (2013), The new normal of Chinese development, in R. Garnaut, F. Cai and L. Song (eds), China: A new model for growth and development, Canberra: ANU E Press. doi.org/10.22459/CNMGD.07.2013.03.

Lin, J.Y., Cai, F. and Li, Z. (1996), The China Miracle: Development strategy and economic reform, Hong Kong: The Chinese University Press.

Peek, J. and Rosengren, E.S. (1998), Bank consolidation and small business lending: It's not just bank size that matters, Journal of Banking and Finance 22: 799-819. doi.org/ 10.1016/S0378-4266(98)00012-0. 
Shen, Y., Shen, M., Xu, Z. and Bai, Y. (2009), Bank size and small- and medium-sized enterprise (SME) lending: Evidence from China, World Development 37(4): 800-11. doi.org/10.1016/j.worlddev.2008.07.014.

Stiglitz, J. and Weiss, A. (1981), Credit rationing in markets with imperfect information, American Economic Review 71: 181-214.

Zhang, D., Cai, J., Dickinson, D. and Kutan, A. (2016), Non-performing loans, moral hazard and regulation of the Chinese commercial banking system. Journal of Banking \& Finance 63: 48-60. doi.org/10.1016/j.jbankfin.2015.11.010.

Zhang, L. and Gou, Q. (2016), Demystifying China's economic growth: Retrospect and prospect, in A. Calcagno, S. Dullien, A. Márquez-Velázquez, N. Maystre and J. Priewe (eds), Rethinking Development Strategies after the Financial Crisis. Volume II: Country studies and international comparisons, New York: United Nations. doi.org/10.18356/ daa61e24-en. 
This text is taken from The Chinese Economic Transformation: Views from Young Economists, edited by Ligang Song, Yixiao Zhou and Luke Hurst, published 2019 by ANU Press, The Australian National University, Canberra, Australia.

doi.org/10.22459/CET.2019.10 